\title{
NEW RECORDS OF FOSSIL VERTEBRATES FROM THE UPPER CRETACEOUS ADAMANTINA FORMATION (BAURU GROUP), SOUTHEASTERN BRAZIL
}

\author{
Caio Fabricio Cezar GEROTO \\ Reinaldo José BERTINI
}

\begin{abstract}
The Adamantina Formation (Bauru Group), between Lucélia and Irapuru municipalities (northwestern São Paulo State, southeastern Brazil), has been in the last years a very important area for collecting Upper Cretaceous fossil vertebrates. So far, the main groups recovered include Testudines, Crocodyliformes and Dinosauria (Theropoda and Titanosauria). The fossil material is usually disarticulated and fragmented and was collected from very fine-grained sandstones, with muddy matrix and cross-stratification and lamination. Testudines are represented by fragments of carapaces and plastrons. Crocodyliformes are composed only of fragmented osteological remains and isolated teeth. Maniraptora is especially represented by isolated teeth, allowing the identification of the Dromaeosaurinae, Velociraptorinae and Troodontidae clades, in addition to some probable endemic groups. Titanosauria is the most representative and abundant group in these fossil localities, however materials are mainly fragments of ribs and some appendicular bones, without diagnostic osteological elements, like caudal vertebrae. The lithological characteristics of the outcrops suggest a paleoenvironment of braided rivers, in an arid climate, with few vegetation cover.
\end{abstract}

Keywords: Bauru Group, Adamantina Formation, São Paulo State, Maniraptora, Titanosauria.

\section{RESUMO}

NOVOS REGISTROS DE VERTEBRADOS FÓSSEIS DO CRETÁCEO SUPERIOR NA FORMAÇÃO ADAMANTINA (GRUPO BAURU), SUDESTE DO BRASIL. A Formação Adamantina (Grupo Bauru), entre os municípios de Lucélia e Irapuru (noroeste do Estado de São Paulo, sudeste do Brasil), tem sido nos últimos anos uma região muito importante para a prospecção de vertebrados fósseis do Cretáceo Superior. Até agora os principais grupos recuperados incluem Testudinos, Crocodyliformes e Dinosauria (Theropoda e Titanosauria). Os materiais são normalmente desarticulados e fragmentados e foram coletados em arenitos de granulação muito fina com matriz lamítica, com estratificações e laminações cruzadas. Testudinos são representados por fragmentos de carapaças e plastrões, enquanto Crocodyliformes, por restos osteológicos fragmentados e dentes isolados. Maniraptora é representado por dentes isolados, que permitiram a identificação dos clados Dromaeosaurinae, Velociraptorinae e Troodontidae, além de alguns prováveis grupos endêmicos. Titanosauria é o agrupamento mais expressivo e abundante nestas localidades, contudo os materiais são principalmente costelas fragmentadas e ossos apendiculares, sem elementos diagnósticos, como vértebras caudais. As características litológicas dos afloramentos sugerem um paleoambiente de rios entrelaçados em clima árido e possivelmente com pouca cobertura de vegetação.

Palavras-chave: Grupo Bauru, Formação Adamantina, Estado de São Paulo, Maniraptora, Titanosauria. 


\section{INTRODUCTION}

The Adamantina Formation (Bauru Group) is the most widespread sequence of continental sedimentary deposits of the Upper Cretaceous from southeastern Brazil. It outcrops in northwestern São Paulo State, between Lucélia and Irapuru municipalities. During the last twenty years, this area has been important for excavation and study of fossil vertebrates, increasing the knowledge about lithofacies and fossil assemblages (BERTINI 1993, SANTUCCI 1999). In the last twelve years, some new fossil localities with additional material were found (ANDRADE 2002).

The main vertebrate groups found in the area belong to Testudines, Crocodyliformes and Dinosauria (Theropoda and Sauropoda). The material is mostly fragmentary and well preserved, and complete elements are scarce. Testudines are represented by fragments of carapaces and plastrons. Crocodyliformes are represented by isolated teeth, as well as Maniraptora. Titanosauria are mainly represented by appendicular remains.

The paleofauna from northwestern São Paulo State was reported in previous studies (BERTINI 1993, BERTINI et al. 1997, FRANCO \& BERTINI 1997, ANDRADE 2002, SANTUCCI \& BERTINI 2006, ANDRADE \& BERTINI 2008). These authors proposed the existence of some endemism, but also the presence of animals with a wide paleobiogeographic distribution, inhabiting other regions of the Upper Cretaceous of South America (SANTUCCI 2002).

Because of the importance of this region in the excavation and study of fossil vertebrates, collective efforts have been made in the last years, leading to discoveries of new localities and materials. The main objective of this study is to examine and describe specimens collected until now.

\section{MATERIALS AND METHODS}

The specimens described in this study were collected in an area $20 \mathrm{~km}$ around Florida Paulista City (Figure 1), between Lucélia e Irapuru municipalities, and are housed in the collection of the "Grupo de Ciências Luckesi", located in "Escola Estadual José Firpo", Lucélia City, São Paulo State. A considerable number of fossils have been collected by local people, who unfortunately did not gather information about the precise location of the outcrops. Therefore, these fossils cannot be associated with any fossil locality reported by ANDRADE (2002). Fossil prospecting and collecting were not organized and outcrop locations are usually unknown.

There are 34 recognized outcrops in the investigated area, characterized by very finegrained sandstones associated with sandy conglomerates. Six new fossil localities were identified during the field trips, consisting of 40 collecting sites (Figure 1, Table 1). The numbers of the new outcrops follow the list displayed by ANDRADE (2002), since they are located in the same region. In five of these sites, a large amount of fragmented fossils were found, supporting future fossil prospecting. For instance, four ribs, a pubis and an ischium of titanosaurs described in this paper were found in site 40 . This locality is situated in a vicinal road close to Santana Farm, showing massive or laminated (parallel stratification) very fine beige sandstones, with sub-rounded to subangular grains, a strong silty matrix, and carbonate cementation.

The nomenclature used for Testudines and Crocodylomorpha fossils is based on ROMER (1997). Descriptions of the titanosaurians specimens are accompanied by measurements, according to the nomenclature used by WILSON (1999) and POWELL (2003). After mechanical preparation, the specimens were identified by comparison with other materials, based mainly on the literature (CURRIE et al. 1990, FRANCO 1999, WILSON 1999, POWELL 2003, ANDRADE 2005, PINHEIRO 2007) and occasional consultation to collections of UNESP Rio Claro, "Departamento Nacional da Produção Mineral" from Rio de Janeiro, "Centro de Pesquisas Paleontológicas Llewellyn Ivor Price" from Uberaba and "Museu Paleontológico de Monte Alto".

List of institutional abbreviations: CPP: "Centro de Pesquisas Paleontológicas Llewellyn Ivor Price; DGM: "Departamento Nacional da Produção Mineral"; LF: "Grupo de Ciências Luckesi"; MPMA: "Museu de Paleontologia de Monte-Alto".

List of abbreviations follow FRANCO (1999) and POWELL (2003): A.art.: width of the articular surface; Ad.: maximum distal width; Am.: minimum width; Amed.: width between medial borders; Ap.: maximum proximal width; Ap.lt.: lateral apophyses; B: basal length of the tooth; BP: keel inclination of the tooth, related to base; Cc.: cnemial crest; Co.br.: area of attachment of the coracobrachial muscle; C. med.: medial condyle; Cr. Dlepc.: deltopectoral crest; DPM: denticles per millimeter of the tooth keel; F.: foramen; FABL: basal transversal section diagram of the tooth; 


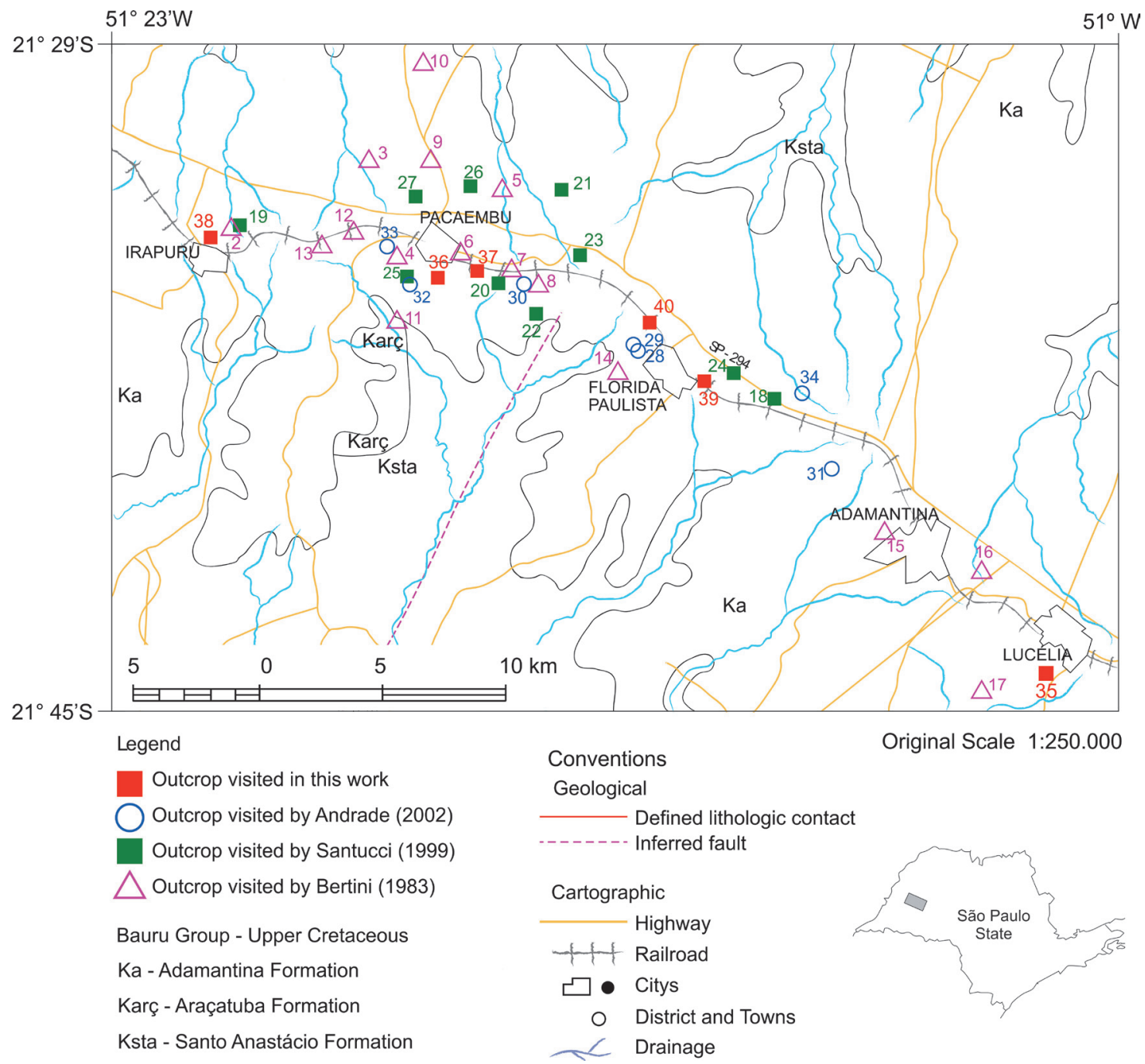

FIGURE 1 - Map of fossiliferous outcrops between Lucélia and Irapuru municipalities, northwestern São Paulo State (Modified from ANDRADE 2002). Sites 1 to 40 are outcrop localities of BERTINI (1993), SANTUCCI (1999), ANDRADE (2002) and GEROTO (2010).

TABLE 1 - Altitude and geographical coordinates of the new outcrops.

\begin{tabular}{|c|c|c|c|}
\hline Locality & Altitude & Latitude & Longitude \\
\hline 35 & 408 & $\mathrm{~S} 21^{\circ} 44^{\prime} 24.2^{\prime \prime}$ & W $51^{\circ} 01^{\prime} 47.7 "$ \\
\hline 36 & 426 & $\mathrm{~S} 21^{\circ} 34^{\prime} 09.1^{\prime \prime}$ & W $51^{\circ} 15^{\prime} 18.5^{\prime \prime}$ \\
\hline 37 & 444 & $\mathrm{~S} 21^{\circ} 34^{\prime} 26.7^{\prime \prime}$ & W $51^{\circ} 14^{\prime} 54.5^{\prime \prime}$ \\
\hline 38 & 461 & $\mathrm{~S} 21^{\circ} 34^{\prime} 01.9^{\prime \prime}$ & W $51^{\circ} 25^{\prime} 12.2^{\prime \prime}$ \\
\hline 39 & 431 & S $21^{\circ} 37^{\prime} 57^{\prime \prime}$ & W $51^{\circ} 09^{\prime} 93^{\prime \prime}$ \\
\hline 40 & 461 & S $21^{\circ} 35^{\prime} 59.29^{\prime \prime}$ & W 51 $1^{\circ} 10^{\prime} 26.63^{\prime \prime}$ \\
\hline
\end{tabular}

H.art.: height of the articular surface; H.t.: total height; L.: total length; L.h.: Lateral lamina of humerus; L.s/art.: length of the vertebral centrum, between anterior and posterior articular surfaces; L.t.: maximum length of the vertebral centrum; Pclp.: posterior centroparapophyseal lamina; Pcdl.: posterior centrodiapophyseal lamina; Pleu.: pleurocelum; Pm.: minimum perimeter of the axis cross section; Prlt.: lateral prominence of the greater trochanter; Poz.: postzygapophysis; Spol.: spinopostzygapophyseal lamina; TCH: total height of the tooth; Tr.m.: greater trochanter; LF - x - R: code of the catalogue numbers from the collection. 


\section{GEOLOGICAL ASPECTS}

Although, in recent years, there has been intense debate about the validity of the term Bauru "Basin", this is beyond the scope of this contribution. Even some geologists (MILANI 1997; PAULA E SILVA et al. 2003, 2005; STRADIOTO et al. 2008) still prefer to consider these deposits (Bauru Group) as belonging to the Paraná Basin, which covers an area of about $350,000 \mathrm{~km}^{2}$ and outcrops in Goiás, Mato Grosso do Sul, Minas Gerais, São Paulo and Paraná states (FERNANDES \& COIMBRA 2000). The Bauru Group comprises a sedimentary sequence outcropping mainly in Western São Paulo State (PAULA E SILVA 2003). It overlies mainly the basaltic rocks of the Serra Geral Formation, and locally the deposits of the Botucatu and Piramboia formations (PAULA E SILVA \& CAVAGUTTI 1994).

The stratigraphic division adopted in this paper is based on proposals from SOARES et al. (1980), BATEZELLI (1998), FERNANDES (1992) and PAULA E SILVA (2003). Therefore, in the São Paulo State, the Bauru Group is divided into Caiuá, Pirapozinho, Santo Anastácio, Birigui, Araçatuba, Adamantina and Marília formations.

This study accepts ages ranging from Upper Campanian to Lower Maastrichtian for the Adamantina Formation, based on assumptions of BERTINI et al. (2000), BERTINI \& SANTUCCI (2001), BERTINI \& MENEGAZZO (2009).

The study area is situated between Lucélia and Irapuru municipalities, Southwestern São Paulo State, showing outcrops of the Adamantina Formation (Figure 1). It is the most widespread geological unit in this region, which was identified along the ridges among rivers, with a thickness of about $190 \mathrm{~m}$ (SOARES et al. 1980).

This geological unit is distinguished from other formations of the Bauru Group by lithofacies changes, which allows many paleoenvironmental interpretations (SOARES et al. 1980). It is usually characterized by fine grained sandstones, pink to brown in color, with cross-stratifications, alternating with mudstones and siltstones, red to gray in color, sometimes massive or laminated (with parallel stratifications), with common ripple marks and cross-laminated stratification.

\section{PRELIMINARY RESULTS}

\subsection{Testudines / LF - 122 - R}

The materials assigned to Testudines, including many remains of carapaces and plastrons, are not diagnostic for a classification, with the exception of a fragment of right xiphiplastron (Table 2 ), presenting fragmented portions of the pelvis.

\subsection{Crocodylomorpha}

$\mathrm{LF}-123$ - $\mathrm{R}$ is a fragment of an indeterminate crocodyliform skull, showing ornamentation of large and deep oval pits, characteristic of some Crocodylomorpha taxons, like Itasuchus jesuinoi and Pepesuchus deiseae (PRICE 1955, CAMPOS et al. 2011).

LF - $124-\mathrm{R}$ is morphologically similar to a Baurusuchidae surangular, showing a dorsal curvature and the glenoid fossa with a posterior edge forming a ridge. Both characteristics are present in the surangular of Baurusuchus pachecoi PRICE, 1945 (DGM 299-R) and Baurusuchus salgadoensis CARVALHO et al., 2005 (MPMA 62-0001-02).

LF - 125 - R corresponds to a long proximal epiphysis of a tibia, which probably corresponds to articulation of the femoral condyles, belonging to Crocodyliformes. The diaphyseal diameter (Table 2) and two articular points, a dorsally flat elongated protuberance and another more laterally displaced one are similar to the proximal epiphysis of a tibia related to Baurusuchus salgadoensis specimens UFRJ 282-R and UFRJ 417-R.

\subsection{Maniraptora}

Maniraptora fossils are frequently fragmentary and not diagnostic. They include an epiphysis of appendicular bone, four probable diaphyses, and a controversial fragment of skull. The appendicular elements are slender and similar to Austroraptor cabazai NOVAS et al., 2009 (GIANECHINI \& APESTEGUÍA 2011).

However, in the outcrops between Lucélia and Irapuru cities, Maniraptora teeth (Table 3) are the most expressive elements associated with this group, and are mainly represented by isolated elements. Fourteen isolated specimens were identified and described, according to CURRIE et al. (1990) and FRANCO (1999).

\subsubsection{Tooth / Velociraptorinae / LF - 016 - R}

This tooth is laterally compressed, with elliptical root shape. The denticles are high, with accentuated interdenticle slits, and rounded tops ending in hook shapes (Figure 2A). Inclination of the keel to the base, number of denticles per millimeter, morphological class of denticles (Table 3), and flattening of the lingual face are 
TABLE 2 - Fossil material identified for each taxon.

\begin{tabular}{|c|c|c|c|}
\hline Taxon & Catologue Number & Material & Origin \\
\hline \multicolumn{4}{|l|}{ Testudines } \\
\hline & LF - $122-\mathrm{R}$ & Right xiphiplastron & surroundings of the Flórida Paulista City \\
\hline \multirow{4}{*}{ Crocodylomorpha } & $\mathrm{IF}-123-\mathrm{P}$ & Skoll fraoment & curroundinge of the Florida Paulict $\mathrm{City}$ \\
\hline & 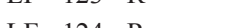 & (2) & . \\
\hline & LF - $124-\mathrm{R}$ & Surangular & surroundings of the Flórida Paulista City \\
\hline & LF - 125 - R & Proximal epiphysis of tibia & surroundings of the Flórida Paulista City \\
\hline \multicolumn{4}{|l|}{ Maniraptora } \\
\hline \multicolumn{4}{|l|}{ Velociraptorine } \\
\hline & $L F-016-R$ & Tooth & surroundings of the Flórida Paulista City \\
\hline & LF - $021-\mathrm{R}$ & Tooth & surroundings of the Flórida Paulista City \\
\hline & $L F-022-R$ & Tooth & surroundings of the Lucélia City \\
\hline \multicolumn{4}{|l|}{ Dromaeosauriae } \\
\hline & LF - $017-\mathrm{R}$ & Tooth & surroundings of the Flórida Paulista City \\
\hline & LF - $018-\mathrm{R}$ & Tooth & surroundings of the Flórida Paulista City \\
\hline & LF - $024-\mathrm{R}$ & Tooth & surroundings of the Lucélia City \\
\hline & LF - $027-\mathrm{R}$ & Tooth & surroundings of the Lucélia City \\
\hline \multicolumn{4}{|l|}{ Troodontidae } \\
\hline & LF - 019 - R & Tooth & surroundings of the Flórida Paulista City \\
\hline & LF - $020-\mathrm{R}$ & Tooth & surroundings of the Flórida Paulista City \\
\hline & LF - $023-\mathrm{R}$ & Tooth & surroundings of the Lucélia City \\
\hline & LF - $026-\mathrm{R}$ & Tooth & surroundings of the Lucélia City \\
\hline & V17 (provisory) & Tooth & surroundings of the Flórida Paulista City \\
\hline \multicolumn{4}{|l|}{$\begin{array}{l}\text { Taxonomical } \\
\text { Group B }\end{array}$} \\
\hline & LF - $025-\mathrm{R}$ & Tooth & surroundings of the Lucélia City \\
\hline \multicolumn{4}{|l|}{$\begin{array}{l}\text { Taxonomical } \\
\text { Group C }\end{array}$} \\
\hline & $L F-028-R$ & Tooth & surroundings of the Lucélia City \\
\hline \multicolumn{4}{|l|}{ Titanosauria } \\
\hline & LF - $007-\mathrm{R}$ & Opisthocelic dorsal vertebra & surroundings of the Flórida Paulista City \\
\hline & LF - $008-R$ & $\begin{array}{l}\text { Centrum of procelic caudal } \\
\text { vertebra }\end{array}$ & surroundings of the Flórida Paulista City \\
\hline & LF - $009-\mathrm{R}$ & $\begin{array}{l}\text { Centrum of procelic caudal } \\
\text { vertebra }\end{array}$ & surroundings of the Flórida Paulista City \\
\hline & LF - $011-\mathrm{R}$ & Right pubis & Locality 40, Santana Farm, Flórida Paulista City \\
\hline & LF - $012-\mathrm{R}$ & Right ischium & Locality 40, Santana Farm, Flórida Paulista City \\
\hline & LF - 1V & Rib & Locality 40, Santana Farm, Flórida Paulista City \\
\hline & $L F-2 V$ & Rib & Locality 40, Santana Farm, Flórida Paulista City \\
\hline & $L F-3 V$ & Rib & Locality 40, Santana Farm, Flórida Paulista City \\
\hline & $\mathrm{LF}-4 \mathrm{~V}$ & Rib & surroundings of the Flórida Paulista City \\
\hline & LF - $001-\mathrm{R}$ & Right humerus & surroundings of the Flórida Paulista City \\
\hline & LF - $002-\mathrm{R}$ & Left humerus & surroundings of the Flórida Paulista City \\
\hline & LF - $006-\mathrm{R}$ & Left humerus & surroundings of the Flórida Paulista City \\
\hline & LF - $003-\mathrm{R}$ & Right femur & surroundings of the Flórida Paulista City \\
\hline & LF - $005-\mathrm{R}$ & Right tibia & surroundings of the Flórida Paulista City \\
\hline
\end{tabular}

characteristics of Velociraptorinae teeth (CURRIE et al. 1990, FRANCO 1999).

\subsubsection{Tooth / Velociraptorinae / LF - 021 - R}

This tooth is laterally flattened. The anterior keel denticles are more worn than the posterior ones, which is a characteristic of Velociraptorinae.
The inclination of the keel (Table 3) to the base of the tooth is similar to the specimens 81 SA and 108 SA, described by FRANCO (1999). The denticles are high, with rounded tops, and assigned to Class 1.2 from CURRIE et al. (1990), related to Velociraptorinae. The interdenticle slits are accentuated (Figure 2F). 

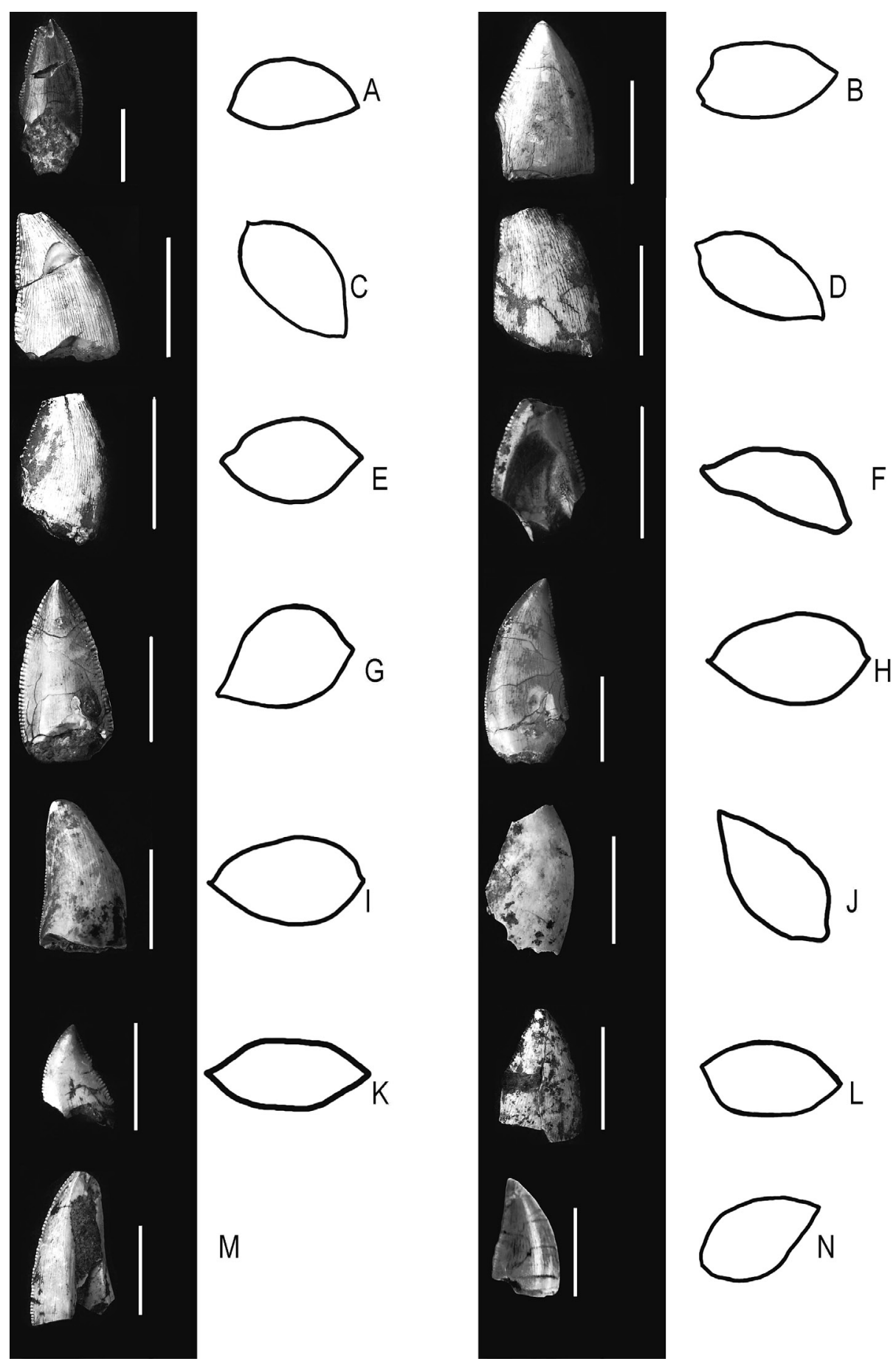

FIGURE 2 - Maniraptora teeth, left columns teeth photographs, right columns FABL schemes: (A) LF - 016 $\mathrm{R}$, lingual view (left), FABL (right); (B) LF - 017 - R, labial view (left), FABL (right); (C) LF - 018 - R, lingual view (left), FABL (right); (D) LF - 019 - R (labial view), FABL (right); (E) LF - 020 - R, labial view (left), FABL (right); (F) LF - 021 - R, lingual view (left), FABL (right); (G) LF - 022 - R, labial view (left), FABL (right); (H) LF - 023 - R, lingual view (left), FABL (right); (I) LF - 024 - R, lingual view (left), FABL (right); (J) LF - 025 - R, lingual view (left), FABL (right); (K) LF - 026 - R, lingual view (left), FABL (right); (L) LF 027 - R, lingual view (left), FABL (right); (M) LF - 028 - R, lingual view; (N) V 17, lingual view (left), FABL (right). Scale bars: $10 \mathrm{~mm}$. 
TABLE 3 - Maniraptora teeth with key features used in identification.

\begin{tabular}{|c|c|c|c|c|c|}
\hline Taxon & Catalog Number & $\mathrm{TCH}$ & $\mathrm{BP}$ & DPM & Denticles Class \\
\hline \multicolumn{6}{|c|}{ Velociraptorinae } \\
\hline & LF - 016 - R & $21 \mathrm{~mm}$ & $=90^{\circ}$ & 3 & 1.2 \\
\hline & LF - $021-\mathrm{R}$ & $11 \mathrm{~mm}$ & $>90^{\circ}$ & 4 & 1.2 \\
\hline & LF - $022-\mathrm{R}$ & $17 \mathrm{~mm}$ & $=90^{\circ}$ & 3 & 1.2 \\
\hline \multicolumn{6}{|c|}{ Dromaeosaurinae } \\
\hline & LF - $017-\mathrm{R}$ & $15 \mathrm{~mm}$ & $>90^{\circ}$ & 3 & 2 \\
\hline & LF - $018-\mathrm{R}$ & $12 \mathrm{~mm}$ & $=90^{\circ}$ & 3 & 2 \\
\hline & LF - $024-\mathrm{R}$ & $14 \mathrm{~mm}$ & $=90^{\circ}$ & 4 & 2 \\
\hline & LF - 027 - R & $11 \mathrm{~mm}$ & $>90^{\circ}$ & 3 & 2 \\
\hline \multicolumn{6}{|c|}{ Troodontidae } \\
\hline & LF - $019-\mathrm{R}$ & $15 \mathrm{~mm}$ & $=90^{\circ}$ & 3 & 1.1 \\
\hline & LF - $020-\mathrm{R}$ & $12 \mathrm{~mm}$ & $=90^{\circ}$ & 3 & 1.1 \\
\hline & LF - $023-\mathrm{R}$ & $21 \mathrm{~mm}$ & $=90^{\circ}$ & 3 & 1.1 \\
\hline & LF - $026-\mathrm{R}$ & $10 \mathrm{~mm}$ & $>90^{\circ}$ & 5 & 1.1 \\
\hline & V17 (provisory) & $11.5 \mathrm{~mm}$ & $=90^{\circ}$ & 3 & 1.1 \\
\hline \multicolumn{6}{|c|}{ Taxonomical Group B } \\
\hline & LF - $025-\mathrm{R}$ & $13 \mathrm{~mm}$ & $=90^{\circ}$ & 4 & $?$ \\
\hline \multicolumn{6}{|c|}{ Taxonomical Group C } \\
\hline & LF - $028-\mathrm{R}$ & $18 \mathrm{~mm}$ & $>90^{\circ}$ & 4 & 3 \\
\hline
\end{tabular}

Total height of the tooth (Table 3) is similar to values measured for the Velociraptorinae teeth described by FRANCO (1999) in the Adamantina Formation. The diagram of the basal cross-section (Figure 2) is similar to the specimen $108 \mathrm{AS}$, which was described by FRANCO (1999).

\subsubsection{Tooth / Velociraptorinae / LF - 022 - R}

The tooth is elongated and flattened on the lingual face, and denticles are high, curved on the tops. The basal cross-section (Figure 2G) is similar to the specimens from FRANCO (1999), which are associated with Velociraptorinae. The total height, inclination of the keel to the base, and denticles per millimeter (Table 3) for this tooth are similar to teeth described by the same author for the Velociraptorinae, which corroborates this association.

\subsubsection{Tooth / Dromaeosaurinae / LF - 17 - R}

This tooth has an elliptical base (Figure 2B). The apex is preserved. The denticles are associated with Class 2 from CURRIE et al. (1990), indicating it could be a Dromaeosaurinae tooth, which can be corroborated by the morphology of the basal cross-section, number of denticles per millimeter, inclination of the keel to the base, and total height (Table 3), all characteristics shared with the teeth of Dromaeosaurinae described by FRANCO (1999). The posterior keel denticles are high, slightly curved, with deep interdenticle slits. The top of the denticles is chisel-like.

\subsubsection{Tooth / Dromaeosaurinae / LF - 018 - R}

This tooth has an elliptical base (Figure 2C). The denticles are high and closed spaced and their top are chisel-like and the interdenticle slits are deep (Figure 2C). The denticles on the posterior keel are point-shaped and not rounded, and, therefore, it could be associated with Class 2 from CURRIE et al. (1990). Total height, inclination of the keel to the base, and denticles per millimeter (Table 3) are characteristics shared by Troodontidae and Dromaeosaurinae teeth, as proposed and described by FRANCO (1999). The diagram of the basal cross-section (Figure 2C) is associated with Morphology 2 from FRANCO (1999), also present in Dromaeosaurinae and Troodontidae. However, the wear pattern of denticles is typical of Dromaeosaurinae. Consequently, it is preferable to associate this tooth with this last group. 
4.3.6 Tooth / Dromaeosaurinae / LF - 024 - R

The inclination of the keel to the base is similar to that of 6 I and 7 I, specimens described by FRANCO (1999). The denticles are high and well developed in lingual view, with apparently chisel-like tops and accentuated interdenticle slits (Figure 2I). This set of characteristics is assigned to Class 2 from CURRIE et al. (1990), which is related to Dromaeosaurinae.

\subsubsection{Tooth Dromaeosauridae / LF - 027 - R}

This tooth is labio-lingually flattened (Figure $2 \mathrm{~L})$. The denticles are high, with chisel-like top and deep interdenticle slits. It can be associated with Class 2 from CURRIE et al. (1990). The total height (Table 3) is close to that of other teeth assigned to Dromaeosaurinae.

\subsubsection{Tooth / Troodontidae / LF - 019 - R}

This tooth has an elliptical base and longitudinal grooves, and is quite laminar (Figure 2D). The denticles are high and have rounded tops, and the interdenticle slits are deep and accentuated. The number of denticles per millimeter (Table 3 ) is associated with Class 1.1 from CURRIE et al. (1990). It is a Troodontidae tooth, which has characteristics similar to many Troodontidae specimens described by FRANCO (1999), such as diagram of the basal cross-section and inclination of the keel (Table 3 ) to the base $\left(90^{\circ}\right)$.

\subsubsection{Tooth Troodontidae / LF - 020 - R}

This is a laterally flattened tooth. The denticles are high, with flap tops, and the interdenticle slits are deep and accentuated (Figure 2E). It shares general features, such as total height, number of denticles per millimeter, inclination of the keel to the base and diagram of the basal cross-section, (Table 3) with specimens assigned to Troodontidae by FRANCO (1999).

\subsubsection{Tooth / Troodontidae / LF - 023 - R}

This tooth is laminar and more laterally flattened than other teeth of this assemblage, with the posterior keel straight and the anterior one curved near the apex (Figure 2H). The denticles are rounded on top, with marked interdenticle slits. The general design is the same of the Class 1.1 from CURRIE et al. (1990). Such morphology was also associated by FRANCO (1999) with Troodontidae. Total height, inclination of the keel to the base, number of denticles per millimeter, and diagram of the basal cross-section (Table 3) are similar to the characteristics defined by FRANCO (1999) for this group.

\subsubsection{Tooth / Troodontidae / LF - 026 - R}

It is a laminar tooth (Figure $2 \mathrm{~K}$ ); denticles are high and rounded on top, with deep interdenticle slits. The general design associates it with Class 1.1 from CURRIE et al. (1990). Denticles per millimeter, diagram of the basal cross-section, and total height (Table 3) seem to indicate that it is a Troodontidae tooth.

\subsubsection{Tooth / Troodontidae ( ? ) / V 17}

This tooth (Figure $2 \mathrm{~N}$ ) has high denticles, with rounded tops, and accentuated interdenticle slits, and was identified as belonging to Class 1.1 from CURRIE et al. (1990). Tooth height and diagram of the basal cross-section are similar to values measured for specimens $3 \mathrm{I}$ and $122 \mathrm{CPP}$ from FRANCO (1999), both showing approximate values of TCH (Table 3). When compared to 3 I and $122 \mathrm{CPP}$, values of inclination of the keel to the base and number of denticles per millimeter (Table 3) are identical to equivalents from V 17.

4.3.13 Tooth / Taxonomic Group B from FRANCO (1999) / LF - 025 - R

It is a laminar tooth; the inclination of the keel to the base is $90^{\circ}$ (Table 3). The similarities between LF - 025 - R and the equivalent teeth described by FRANCO (1999) include significant wear facets of the keels, and general morphology and diagram of the basal cross-section (Figure $2 \mathrm{~J})$, but LF - $025-\mathrm{R}$ is bigger in size. Considering these characteristics, this tooth was assigned to Taxonomic Group B of FRANCO (1999).

4.3.14 Tooth / Taxonomic Group C from FRANCO (1999) / LF - 028 - R

The tooth is less labio-lingually flattened than the previous one (Figure 2M). The denticles are short, with equivalent height and width, deep interdenticle slits and chisel-like tops. Therefore, it can be assigned to Class 3 proposed by FRANCO (1999). The total height (Table 3) is $1 \mathrm{~cm}$, higher than the biggest Dromaeosaurinae tooth described by FRANCO (1999). This tooth has 4 denticles per millimeter (Table 3), and, according to FRANCO (1999), no other Dromaeosaurinae tooth has this 
number of denticles. The measurements of the keel inclination to the base and the number of denticles per millimeter are similar to those of teeth associated with the Taxonomic Group $\mathrm{C}$ of FRANCO (1999).

\subsection{Titanosauria}

This group is very abundant in the study area, with diverse isolated and fragmentary vertebrae and ribs, as well as appendicular elements. But unfortunately they are not diagnostic (Table 4).
4.4.1 Dorsal Vertebrae / Titanosauria / LF 007 - R

This is an opisthocoelic dorsal vertebrae, assigned to Titanosauria due to the presence of well-developed pleurocoels and laminae, and considered synapomorphies of the group (WILSON 2002) (Table 4). Only the posterior region and part of the vertebral centrum were preserved. The most anterior portion of the vertebrae is absent, with very damaged laminae (Figure 3).

TABLE 4 - Titanosaurian material and measurements.

\begin{tabular}{|c|c|c|}
\hline Catalog Number & Titanosaurian materials & Measures \\
\hline LF - $007-\mathrm{R}$ & Opisthocelic dorsal vertebra & H.art.: $950 \mathrm{~mm}$; A.art.: $110 \mathrm{~mm}$; H.t.: $110 \mathrm{~mm}$; L.t.: $90 \mathrm{~mm}$ \\
\hline LF - $008-\mathrm{R}$ & Centrum of procelic caudal vertebra & H.art.: $50 \mathrm{~mm}$; A.art.: $70 \mathrm{~mm}$; L.t.: $85 \mathrm{~mm}$; L.s/art.: $80 \mathrm{~mm}$ \\
\hline LF - $009-\mathrm{R}$ & Centrum of procelic caudal vertebra & H.art.: $50 \mathrm{~mm}$; A.art.: $60 \mathrm{~mm}$; L.t.: $100 \mathrm{~mm}$; L.s/art.: $120 \mathrm{~mm}$ \\
\hline LF - $011-\mathrm{R}$ & Right pubis & L.: 400 mm; Ap.: 500 mm; Am.: 260 mm \\
\hline LF - $012-\mathrm{R}$ & Right ischium & L.: 490 mm; Am.: 200 mm. \\
\hline $\mathrm{LF}-1 \mathrm{~V}$ & Rib of Titanosauria & L.: 950mm; Pm.: $83 \mathrm{~mm}$ \\
\hline$L F-2 V$ & Rib of Titanosauria & L.: 1000 mm; Pm.: 110 mm \\
\hline $\mathrm{LF}-3 \mathrm{~V}$ & Rib of Titanosauria & L.: 870 mm; Pm.: $90 \mathrm{~mm}$ \\
\hline LF - 4V & Rib of Titanosauria & L.: $580 \mathrm{~mm} ;$ Pm.: $135 \mathrm{~mm}$ \\
\hline LF - $001-\mathrm{R}$ & Right humerus & L.: 790 mm (?); Ap.: 280 mm; Ad.: 190 mm; Pm.: 300 mm (?) \\
\hline LF - $002-\mathrm{R}$ & Left humerus & L.: 800 mm; Ap.: 270 mm; Ad.: 190 mm; Pm.: 330 mm \\
\hline LF - $006-\mathrm{R}$ & Left humerus & L.: 430 mm; Ap.: 190 mm; Ad.: 170 mm; Pm.: 320 mm \\
\hline LF - $003-\mathrm{R}$ & Right femur & L.: 1000 mm; Ap.: 260 mm; Ad.: 260 mm; Pm.: 380 mm \\
\hline LF - $005-\mathrm{R}$ & Right tibia & L.: 200 mm; Ap.: $200 \mathrm{~mm}$ \\
\hline
\end{tabular}

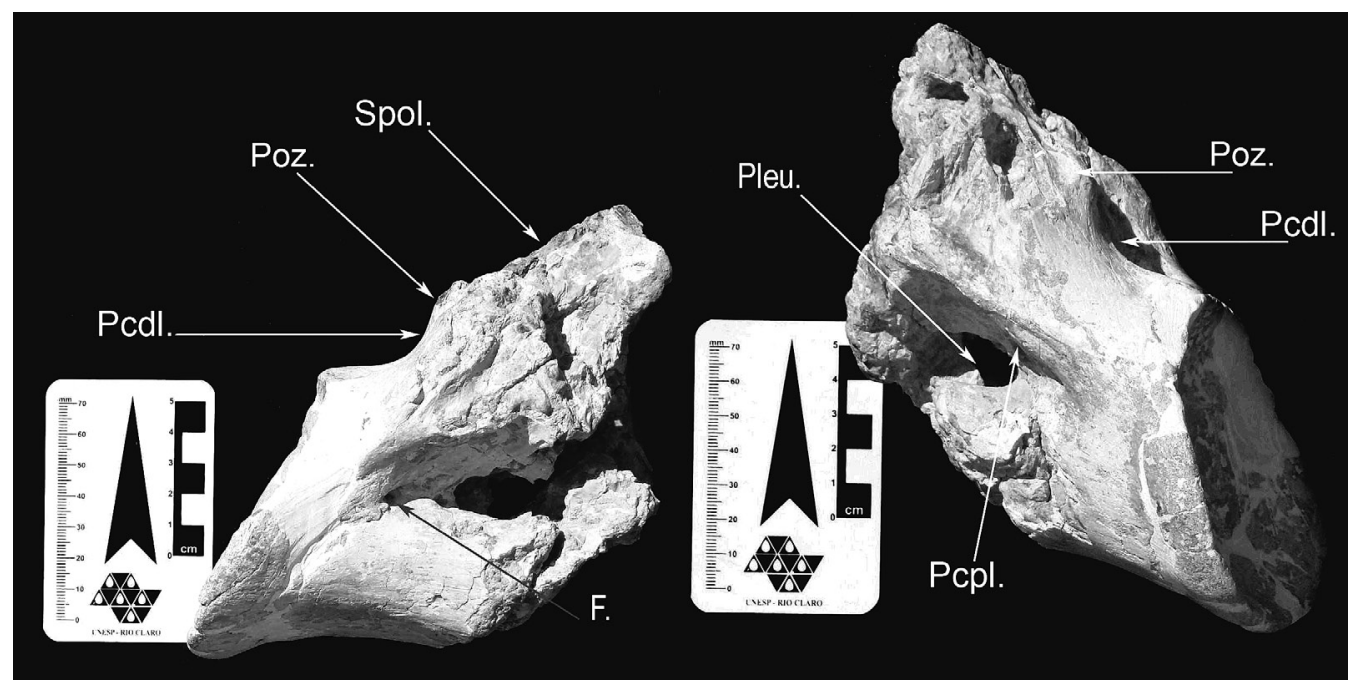

FIGURE 3 - LF - 007 - R, caudal vertebrae, left lateral view (left); right lateral view (right). Scale in centimeters. 
The posterior articular surface is ventrally deformed, and one margin is longer than the other, like Saltasaurus loricatus. Pre- and postzygapophyses are fragmented on their ends and the anterior articulation surface is absent. The neural canal measures $55 \mathrm{~mm}$ in length and $35 \mathrm{~mm}$ in diameter. It is not possible to visualize any of the transverse processes. However, it is possible to observe their positions, and all are above the vertebral centrum.

The postzygapophyses are posteriorly inclined and almost parallel to the vertebral centrum, which was caused by deformation during fossilization. The posterior centrodiapophyseal lamina is present on the right lateral face, but is fragmented on the left one (Figure 3).

The posterior centroparapophysial lamina is present on both faces of the vertebral centrum, with a foramen on the base. The suprapostzygapophysial lamina is fragmented and almost absent, as well as the transverse processes (Figure 3 ). In anterior view, it is similar to a medium dorsal vertebrae of Saltasaurus loricatus (POWELL 2003).

The pleurocoels are evident, parallels to each other, and situated above the vertebral centrum. There are two foramens at the entrance of the pleurocoel, more visible on the right lateral face. These pleurocoels allow its identification as a dorsal vertebrae of Titanosauria (WEDEL 2005).

\subsubsection{Caudal Vertebrae / Titanosauria / LF -} 008 - R

It is a centrum of procoelic caudal vertebrae, with a large socket on the anterior articulation surface and a ball on the posterior articulation surface, which are characteristics of Titanosauria vertebrae (POWELL 2003). The diameter of the center is similar to values measured by POWELL
(2003) for a great number of Titanosauria (Table 4). It is not possible to observe many structures in the specimen, only the central portion of the neural arch (Figure 4B), but the morphology is identical to that of a caudal vertebrae of Uberabatitan riberoi SALGADO \& CARVALHO, 2008 (CPP 1009UrHO, CPP 1010-UrHO, CPP 1008-UrB).

\subsubsection{Centrum of Vertebrae / Titanosauria /} LF - 009 - R

A centrum of vertebrae (Table 4) without significant structures was preserved. There is only evidence of the neural arch, which is slightly central-laterally flattened and more dorso-ventrally flattened, creating semi-plane surfaces (Figure 4A). Its similarity with Titanosauria vertebrae is supported by morphological comparison with the caudal vertebrae of titanosaurians described by POWELL (2003).

\subsubsection{Right Pubis / Titanosauria / LF - 011 - R}

This was identified as the proximal portion of a right pubis of Titanosauria (Table 4). It is possible to observe an open obturator foramen in the anterior region of the pubis (Figure 5). In addition, there is a prominent curve, which seems to have some continuity, but is absent in the distal part of the specimen. The position of these morphological elements is similar to that shown in figures of a Camarasaurus pubis from WILSON \& SERENO (1998). Therefore, the reconstruction of the specimen was based on that genus.

\subsubsection{Right Ischium / Titanosauria / LF - 012} $-\mathrm{R}$

The specimen, which is very damaged, was associated with LF - 011 - R (Table 4). Below the

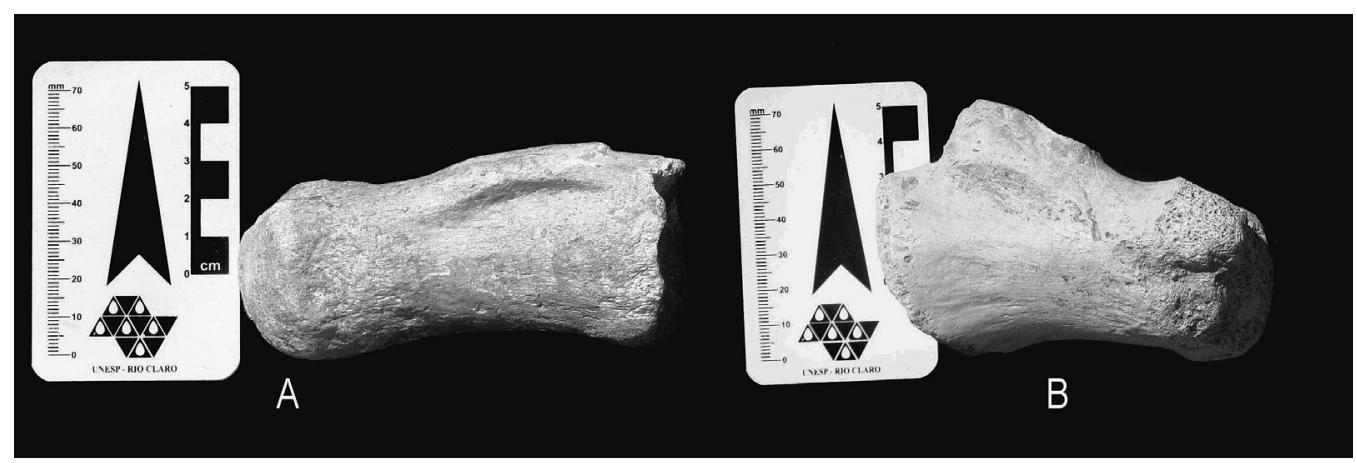

FIGURE 4 - (A) LF - 009 - R, centrum of caudal vertebrae, right lateral view; (B) LF - 008 - R, centrum of caudal vertebrae, right lateral view. Scale in centimeters. 

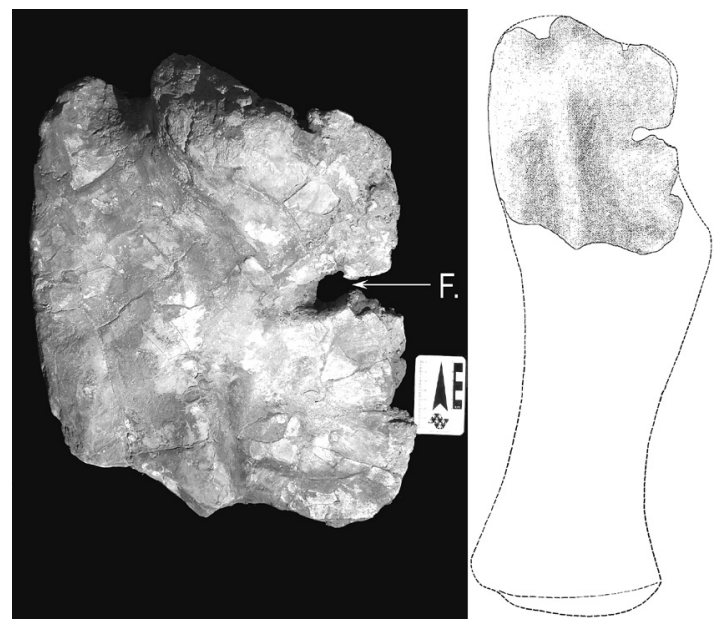

FIGURE 5 - Proximal portion of a right pubis of Titanosauria (LF - 011 - R), lateral view. Reconstruction of the right pubis LF - 011 - R, using the equivalent of Camarasaurus. Scale in centimeters.

lamina, there is a depression, which is also present in the rest of the specimen. There is an entry at the beginning of this lamina, forming a right angle. The superior and inferior portions of this lamina do not show evidence of fragmentation or indications of articulation points. Due to morphological similarities with an ischium of Aeolosaurus rionegrinus described by POWELL (2003), it can be referred to as an ischium lamina (Figure 6).

\subsubsection{Ribs / Titanosauria}

Four ribs (Figure 7A-D) were collected from the study area, three of them (LF - 1V, LF - $2 \mathrm{~V}$ and LF - 3V) were associated with LF - 011 - R and LF
- 012 - R from Santana Farm, Locality 40 (Table 1), Flórida Paulista City. The ribs are long and robust, similarly to titanosaurian equivalents described by WILSON (2002).

LF - 1V (Table 4) is damaged, fragmented in many pieces, with no epiphyses.

LF - 2V (Table 4) has many fracture points, but the proximal epiphysis and the articulation region of the vertebrae are preserved, the latter as a bifurcate arch, with one of the extremities absent and the other showing some extension. This rib is thicker than other two collected from the same locality, showing minor differences in length.

LF - 3V (Table 4) preserves a fragment of the proximal epiphysis, and the distal epiphysis is absent. The width is constant, increasing after the preserved area, and becoming more flattened.

LF - 4V (Table 4) is slightly curved in length, very fragmented, consisting only of the diaphysis, lacking proximal epiphysis, articulation area for the vertebrae, and distal diaphysis.

\subsubsection{Left Humerus / Titanosauria LF - 002 - R}

This humerus (Table 4) is associated with this group due to its square latero-dorsal corner, which is a characteristic of titanosaurs (Figure 8 A-B) (POWELL 2003). The specimen is damaged along its length, with fissures. Parts of the proximal epiphysis and the diaphysis were repaired with Plaster of Paris. The margin of the posterior concavity of the proximal epiphysis is less prominent, progressively joining the humerus diaphysis.

In anterior view, the area for insertion of the coracobrachialis muscle is broken. The region between the coracobrachialis muscle and the superior

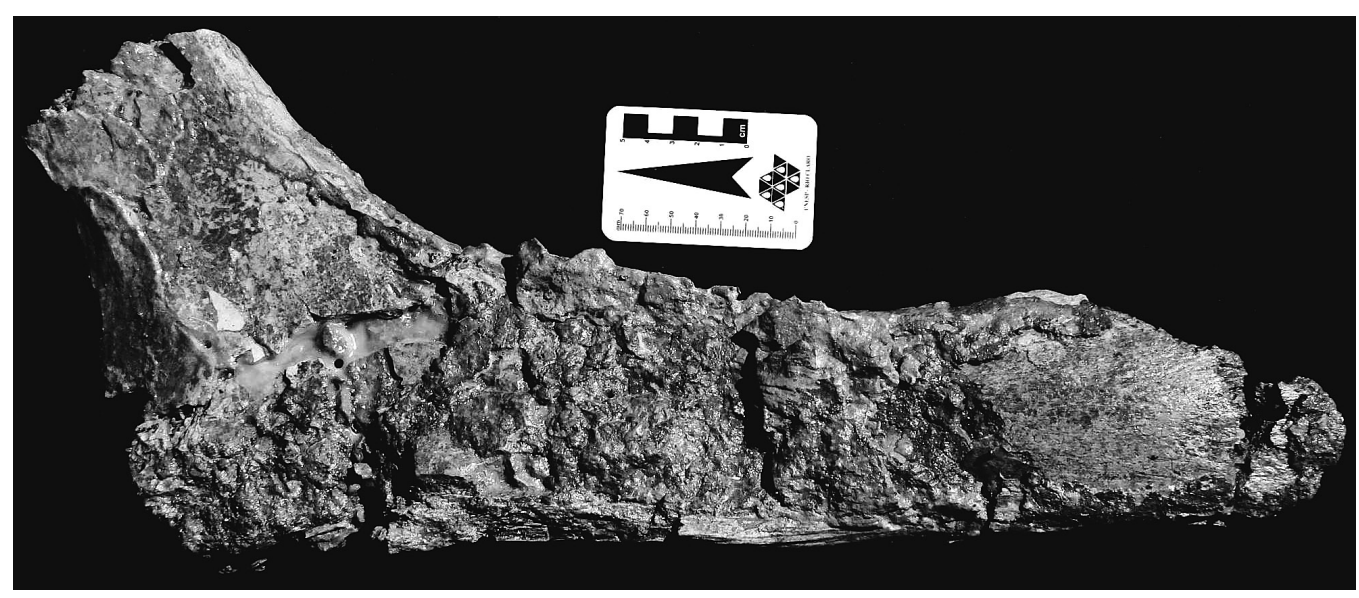

FIGURE 6 - Fragment of Titanosauria right ischium (LF - 012 - R), lateral view. Scale in centimeters. 

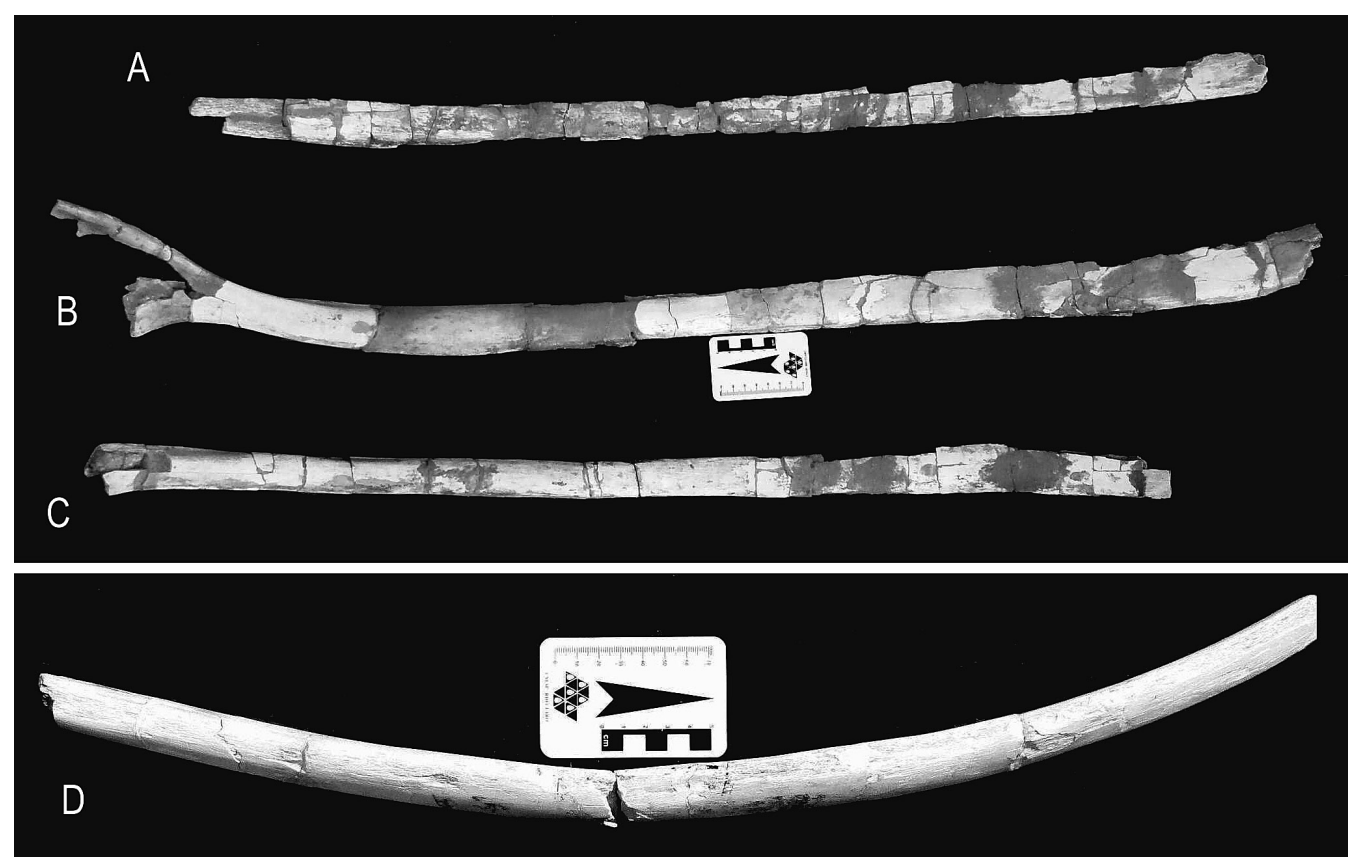

FIGURE 7 - Titanosauria ribs: (A) LF - 1V; (B) LF - 2V; (C) LF - 3V; (D) LF - 4V. Scale in centimeters.

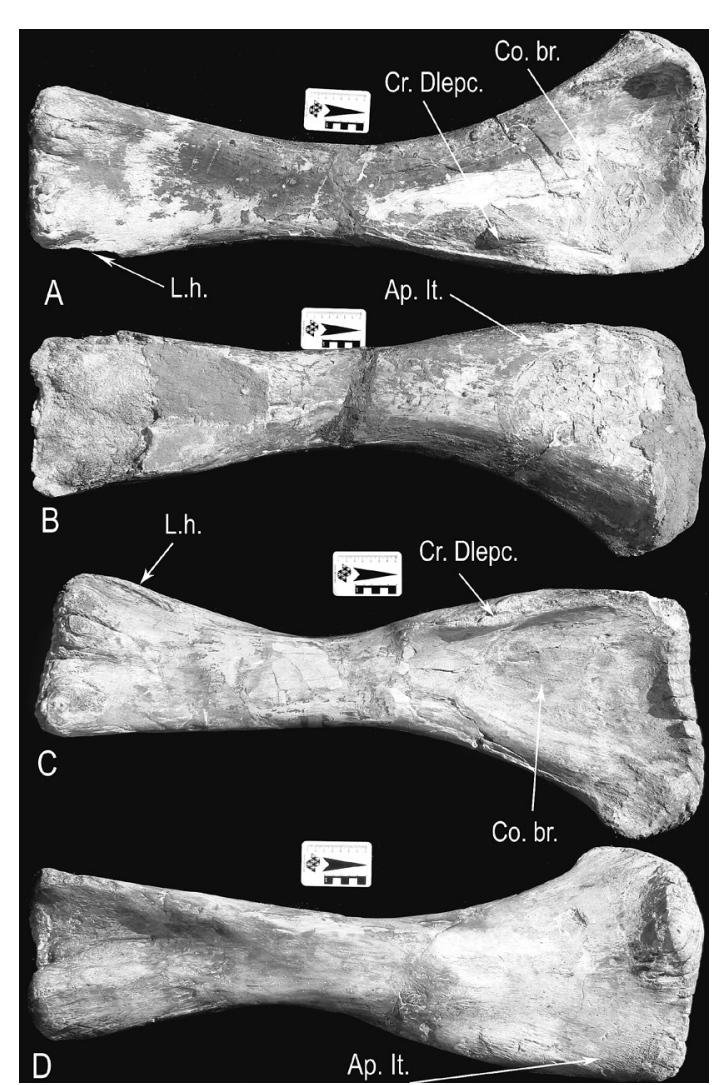

FIGURE 8 - LF - 002 - R, left humerus, (A) anterior view, (B) posterior view. LF - 001 - $R$, right humerus, (C) anterior view, (D) posterior view. Scale in centimeters. portion of the proximal epiphysis is concave, long, and shallow. The deltopectoral crest is more prominent when compared to Saltasaurus (BONAPARTE \& POWELL 1980), and its morphology is more similar to the morphology observed in Argyrosaurus (POWELL 2003), but it does not reach the external margin of the anterior face.

The posterior face of the distal epiphysis is damaged up to the region of the radius / ulna articulation. On the anterior face of the distal epiphysis, it is possible to observe a small lamina, extending to its end. Although fragmented, this lamina (L.h. in the Figure 8) measures $100 \mathrm{~mm}$ in length and at least 20 $\mathrm{mm}$ in height in its highest point.

\subsubsection{Right Humerus / Titanosauria / LF - 001} $-\mathrm{R}$

The maximum length and cross-section of the diaphysis may not be correct because the present specimen was fragmented (Table 4). It was subsequently restored, but the point of break in the diaphysis is still visible in the images (Figures 8C-D).

The coracobrachialis fossa is very pronounced and well-demarcated (Figure 8C), as well as short and deep, similarly to Saltasaurus (BONAPARTE \& POWELL 1980). The square laterodorsal region and the dimensions associate this right humerus with Titanosauria. 
The deltopectoral crest is well preserved and developed and aligned to the antero-lateral margin of the humerus. The area for attachment of the coracobrachialis muscle is also intact and very prominent. The anterior and posterior faces of the proximal epiphysis are slightly damaged. The diaphysis is completely broken, dividing the humerus into two parts. The distal epiphysis is well preserved, with both radial and ulnar condyles slightly damaged. There is a lamina (L.h. in the Figure 8) in the anterior region of the distal epiphysis, next to the condyle of the radius articulation, measuring $110 \mathrm{~mm}$ in length and $20 \mathrm{~mm}$ in height.

\subsubsection{Left Humerus / Titanosauria / LF - 006 - R}

This specimen has the same morphology of LF - 002 - R, which makes it possible to identify it as a left humerus of Titanosauria. The material is fragmented, and its identification was possible by examining the well-demarcated inferior margin of the coracobrachialis fossa (ROMER 1997, POWELL 2003) and by analyzing its dimensions (Figure 9). Despite fragmentation, the absence of both epiphysis and its dimensions suggest it was a robust bone (Table 4).

It is possible to observe part of the deltopectoral crest and part of the coracobrachialis fossa, allowing the identification of the anterior view (Figure 9). The specimen is anteroposteriorly flattened, and in antero-posterior view, its external border is straighter than the internal one, which is concave, indicating it would be a left humerus.

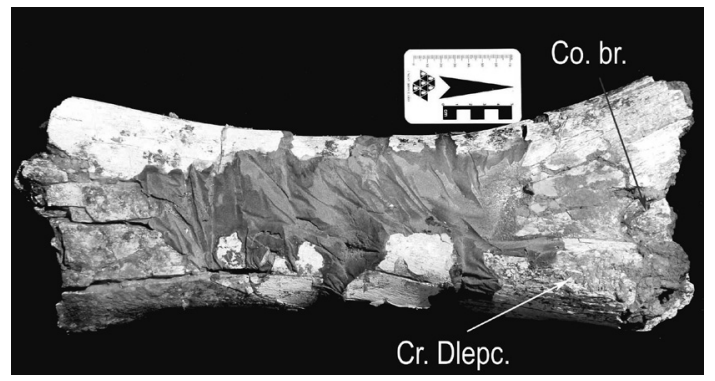

FIGURE 9 - LF - 006 - R, left humerus, anterior view. Scale in centimeters.

\subsubsection{Right Femur / Titanosauria / LF - 003 - R}

This is an antero-posteriorly flattened (Figure 10) long bone (Table 4), with a typical morphology of a femur of sauropod (CARRANO
2005) and a bigger trochanter parallel to the femoral condyle, which makes it possible to identify it as a titanosaur femur (UPCHURCHU et al. 2007). The identification was made comparing it with the femur of Saltasaurus loricatus (POWELL 2003; Plate 44).

In anterior view, (Figure 10) the femoral condyle extends to the left medial portion of the bone, indicating it is a right femur. It is broken into three parts. Unfortunately, some complementary fragments from these fractured areas are missing.

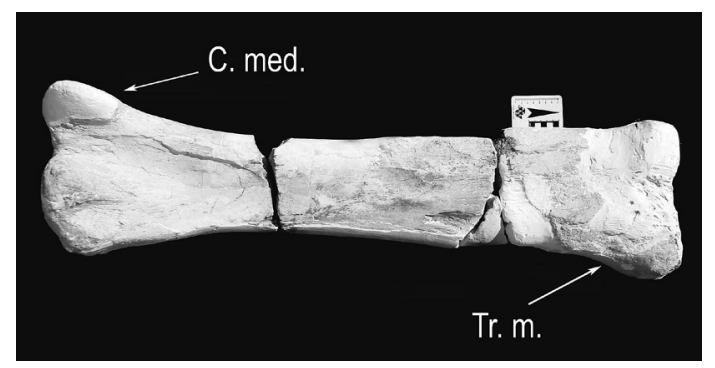

FIGURE 10 - LF - 003 - R, right femur, anterior view. Scale in centimeters.

The articulation area of the proximal epiphysis is broken, almost absent, and covered by Plaster of Paris, which means a restoration was attempted during preparation. The great trochanter is damaged and also covered by Plaster of Paris, with an inconspicuous lateral prominence. The medial condyle is salient and slightly harmed, and the fourth trochanter region is also damaged (structures according POWELL 2003, Plate 44).

Below the proximal epiphysis, next to the fourth trochanter, there is an almost flat area, slightly detached, which is possibly a muscle insertion point. Both proximal condyles are well preserved, despite the presence of Plaster of Paris on the medial condyle.

\subsubsection{Right Tibia / Titanosauria / LF - 005} - R

It is a proximal epiphysis of an appendicular bone, possibly a right tibia (Table 4). Its shape and characteristics are similar to those of a Titanosaurus right tibia, when compared to figures of Plate 5, page 98, and Plate 12, page 105, from POWELL (2003). On the posterior face, it is possible to observe the articulation area to the femoral condyles. The cnemial crest is preserved, although there are some small fractures. The depression in the posterior region of the cnemial crest is prominent (Figure 11). 


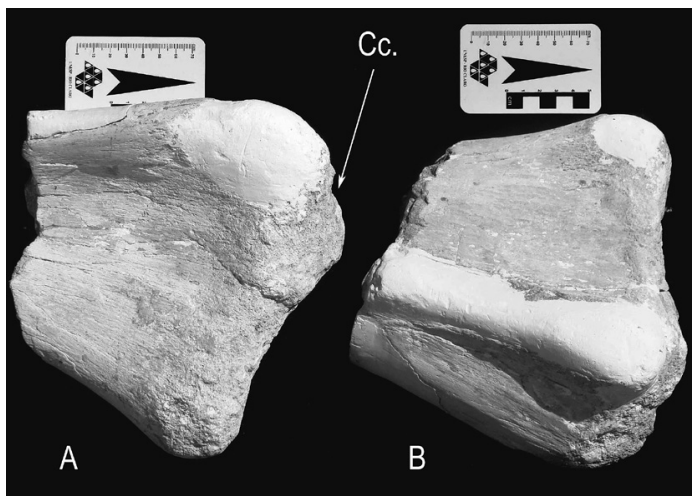

FIGURE 11 - LF - 005 - R, right tibia, (A) posterior view; (B) fibular view. Scale in centimeters.

\section{DISCUSSION AND CONCLUSIONS}

The fossil-bearing layers are composed mainly of very fine-grained sandstones, with muddy matrix and cross- and parallel stratifications and laminations. It is possible to observe that the sedimentary facies of the Adamantina Formation show cyclicity, with alternating humid and arid seasons.

The fossil material comprises diverse fragments of Testudines, Crocodylomorpha, Maniraptora, and Titanosauria, the last two being the most significant. Much of the material found in the area is fragmented in small pieces. Some fossils are disarticulated, few are associated with other bones and / or articulated. Diagenetic reasons can be the cause of fragmentation of some fossils.

Some fossils show evidence of transport, such as the vertebral centra LF - 008 - R and LF - 009 - R. Other materials show evidence of deformation during diagenesis, like the dorsal vertebrae LF - 007 - R, which is antero-dorsally flattened. Other fossils show evidence of reworking and weathering after diagenesis, such as LF - 006 - R, LF - 011 - R, LF - 012 - R, LF $1 \mathrm{~V}, \mathrm{LF}-2 \mathrm{~V}, \mathrm{LF}-3 \mathrm{~V}$ and $\mathrm{LF}-4 \mathrm{~V}$.

Fragments of turtles and crocodyliformes also show signs of weathering. Appendicular bones with abraded extremities of epiphyses and Maniraptora teeth with broken roots were also collected in the study area.

This kind of preservation supports interpretations like prolonged exposure in a semiarid and warm paleoenvironment (FERNANDES 1998). Since most bone remains are disarticulated and even displaced, separated by some distance, one possible explanation is the transport of the material, possibly with long exposure, from death to burial (HOLZ \& SIMÕES 2002).
The fragmentation of other fossils could be caused by weathering, since some bones do not show typical helical fractures, indicating exposure before burial. The fractures are mainly transverse, suggesting there was breakage while they were embedded in sedimentary rock.

Some of the Titanosauria elements (LF - 003 - R, LF - 005 - R, LF - 007 - R, LF - 008 - R, LF 009 - R, LF - 010 - R, LF - 1V - R, LF - 2V - R, LF $3 \mathrm{~V}-\mathrm{R}, \mathrm{LF}-4 \mathrm{~V}-\mathrm{R}$ ) have a whitish color, probably a result of calcium carbonate concentration in paleoenvironments, during fossilization. It is not common for materials from the outcrops of the Adamantina Formation around Flórida Paulista Municipality. Future studies can evaluate, using thin sections of the material, if there was some kind of structural modification in these bone remains.

The clade Titanosauria is represented by some axial and appendicular remains. In the Bauru Group, six species were described: Gondwanatitan faustoi KELLNER \& AZEVEDO, 1999, Trigonosaurus pricei CAMPOS et al., 2005, Baurutitan britoi KELLNER et al., 2005, Adamantisaurus mezallirai SANTUCCI \& BERTINI, 2006, Uberabatitan ribeiroi SALGADO \& CARVALHO, 2008 and Aeolosaurus maximus SANTUCCI \& ARRUDACAMPOS, 2011.

Evidence collected from the study area regarding titanosaurian does not provide morphological indication for the identification of specific morphotypes. Taxonomic classification for this group was based on well-preserved vertebrae, with diagnostic anatomical/morphological elements. The axial elements are fragmented, with no significant morphological features.

The best preserved titanosaurian specimens are appendicular bones, ribs, remains of pelvic girdles, which do not provide morphological evidence for comparison. It is not possible to relate any of the Titanosauria remains to Adamantisaurus mezzalirai (SANTUCCI \& BERTINI 2006), the only titanosaurid taxon described from the region until now.

LF - $007-\mathrm{R}$ is a fragmented opisthocoelic dorsal vertebrae, with some characteristics similar to Saltasaurus loricatus (POWELL 2003). LF - 002 $-\mathrm{R}$ is a left humerus, showing affinities with the equivalent of Argyrosaurus superbus (POWELL 2003). LF - 012 - $\mathrm{R}$ is an ischium with close affinities to Aeolosaurus rionegrinus. However, it is not possible to establish a relationship between them, and these morphotypes belong to an assemblage considered Upper Campanian / Early Maastrichtian in age (BONAPARTE \& POWELL 1980, BONAPARTE et al. 1984, UPCHURCH et al. 2007). 
The possible presence of Aeolosaurus maximus in the deposits of the Adamantina Formation shows its chronological importance, due to correlation with occurrences of this genus in Argentina, whose remains are found with hadrosaurs, indicating Campanian to Maastrichtian age for those localities, interpreted as a result of landmass connection between North and South America in this time interval (POWELL 1987, BONAPARTE 1992, SALGADO et al. 1997, SANTUCI \& ARRUDA-CAMPOS 2011).

The material associated with Maniraptora is mainly represented by teeth. According to CURRIE et al. (1990) and FRANCO (1999), they can be assigned to Dromaeosaurinae, Velociraptorinae and Troodontidae, as well as to some endemic taxonomic groups from the Bauru Group.

In the study area, teeth of Velociraptorinae (LF - 016 - R, LF - 021 - R, LF - 022 - R), Dromaeosaurinae (LF - 017 - R, LF - 018 R, LF - 024 - R, LF - 027 - R), Troodontidae (LF - 019 - R, LF - 020 - R, LF - 023 - R, LF - 026 $\mathrm{R}, \mathrm{V} 17)$, Taxonomic Group B (LF - 025 - R), and Taxonomic Group C (LF - 028 - R) were identified using parameters defined by CURRIE et al. (1990) and FRANCO (1999).

Until now, the only records of Maniraptora dinosaurs from the Bauru Group are teeth, an ungual phalanx (NOVAS et al. 2005) and an opisthocoelic vertebrae associated with Unenlagiidae (CANDEIRO et al. 2012), a subfamily of Dromaeosauridae, with representatives in Argentina and Madagascar (GIANECHINI \& APESTEGUIA 2011). In Brazil, other Velociraptorinae representatives are found only in the Middle Cretaceous of the São-Luis Grajaú Basin (ELIAS et al. 2007).

FRANCO (1999) assumed that Maniraptora teeth from the Bauru Group, Adamantina and Marília formations, are mainly associated with Dromaeosaurinae, Velociraptorinae and Troodontidae. Teeth of Dromaeosaurinae, Velociraptorinae and Troodontidae from the Judith River Formation were interpreted as Campanian in age by CURRIE et al (1990).

The same groups of Maniraptora and Titanosauria are identified in the study area. Based on biochronological data about these Maniraptora in North America and Titanosauria in Argentina, these deposits could be interpreted as Campanian - Maastrichtian in age. Furthermore, the presence of Dromaeosaurinae, Velociraptorinae and Troodontidae in North and South American deposits corroborates the hypothesis of a landmass bridge between these two continents in CampanianMaastrichtian interval.

\section{ACKNOWLEDGEMENTS}

This research was supported by $\mathrm{CNPq}$ $(401795$ / 2010 - 1). The authors would like to thank M.Sc. Paulo Sérgio Fiorato for providing access to material for analysis and all students of the "Grupo de Ciências Luckesi" for their dedication in collecting and preparing some of these fossils. They are also grateful to Leila Rangel da Silva for taking pictures during her free time and to the anonymous reviewers, whose comments and suggestions greatly improved this paper.

\section{REFERENCES}

ANDRADE, L.R.M. 2002. Levantamentos litofaciológico e paleobiológico, com interpretações paleoecológicas, em sedimentos da Bacia Bauru - Cretáceo Superior, ao longo da Rodovia SP 294, entre as cidades de Adamantina e Dracena. Instituto de Geociências e Ciências Exatas, Rio Claro, Trabalho de Conclusão de Curso, 105 p.

ANDRADE, M.B. 2005. Revisão sistemática e taxonômica dos Notosuchia (Metasuchia, Crocodylomorpha). Instituto de Geociências e Ciências Exatas, Rio Claro, Dissertação de Mestrado, $239 \mathrm{p}$.

ANDRADE, M.B.; BERTINI, R.J. 2008. Morphological and anatomical observations about Mariliasuchus amarali and Notosuchus terrestris (Mesoeucrocodylia) and their relationships with other South American notosuchians. Arquivos Museu Nacional, 66(1): 5-62.

BATEZELLI, A. 1998. Redefinição estratigráfica da Unidade Araçatuba, de sua extensão regional na Bacia Bauru no Estado de São Paulo. Instituto de Geociências e Ciências Exatas, Universidade Estadual Paulista, Rio Claro, Dissertação de Mestrado, 110 p.

BERTINI, R.J. 1993. Paleobiologia do Grupo Bauru, Cretáceo Superior continental da Bacia do Paraná, com ênfase em sua fauna de amniotas. Instituto de Geociências, Universidade Federal do Rio de Janeiro, Rio de Janeiro, Tese de Doutoramento, 493 p. 
BERTINI, R.J.; MENEGAZZO, M.C. 2009. Reflections about Geology and Biochronology of the "Bauru Basin" deposits. In: SBG, SIMPÓSIO DE GEOLOGIA DO SUDESTE, 11, São Pedro, Anais, p. 71.

BERTINI, R.J.; SANTUCCI, R.M. 2001. Titanosaurids (Saurischia, Sauropoda) from Southeastern Brazil. Journal of Vertebrate Paleontology, 20(3): 56A-57A.

BERTINI, R.J.; FRANCO, A.C.; TOLEDO, C.E.; ARRUDA-CAMPOS, A.C. 1997. Theropod teeth from Adamantina Formation, Upper Cretaceous of São Paulo State. Analisys of the dental morphology. In: SBP, CONGRESSO BRASILEIRO DE PALEONTOLOGIA, 15, São Pedro, Boletim de Resumos, p. 103.

BERTINI, R.J.; GOBBO-RODRIGUES, S.R.; SANTUCCI, R.M. 2000. O Grupo Bauru e sua Biocronologia. In: SBP, PALEO 2000, Botucatu, Boletim de Resumos, p. 4.

BONAPARTE, J.F. 1992. Uma neuva especie de Triconodonta (Mammalia) de La Formación Los Alamitos, Província de Río Negro y comentarios sobre su fauna de mamiferos. Ameghiniana, 29: 99-100.

BONAPARTE, J.F.; POWELL, J.E., 1980. A continental assemblage of tetrapods from the Upper Cretaceous beds of El Brete, Northwest Argentina (Sauropoda - Coelurosauria - Carnosauria - Aves). Mémoire Societé Géologique France N. S., 139: 19-28.

BONAPARTE, J.F.; FRANCHI, M.R.; POWELL, J.E.; SEPULVEDA, E.G. 1984. La Formación Los Alamitos (Campaniano - Maastrichtiano) del Sudeste de Río Negro, con descripción de Kritosaurus australis n. sp. (Hadrosauridae). Significado paleogeográfico de los vertebrados. Revista de la Asociación Geológica Argentina, 49(3-4): 284-299.

CAMPOS, D.A.; KELLNER, A.W.A.; BERTINI, R.J.; SANTUCCI, R.M. 2005. On a titanosaur (Dinosauria, Sauropoda, Titanosauridae) vertebral column from Brazil. Arquivos do Museu Nacional, 63(3): 565-593.

CAMPOS, D.A.; OLIVEIRA, G.R.; FIGUEIREDO, R.G.; RIFF, D.; AZEVEDO, S.A.K.; CARVALHO, L.B.; KELLNER, A.W. A.
2011. On a new peirosaurid crocodyliform from the Upper Cretaceous, Bauru Group, Southeastern Brazil. Anais da Academia Brasileira de Ciências, 83(1): 317-327.

CANDEIRO, C.A.; CAU, A.; FANTI, F.; NAVA, W.R.; NOVAS, F.E. 2012. First evidence of an unenlagiid (Dinosauria, Theropoda, Maniraptora) from the Bauru Group, Brazil. Cretaceous Research, 37: 223-226.

CARRANO, M.T. 2005. The evolution of sauropod locomotion. In: K.C. Rogers \& J.A. Wilson (Ed.) The sauropods: evolution and paleobiology. Los Angeles, University of California Press, p. 229-249.

CARVALHO, I.S.; ARRUDA-CAMPOS, A.C.; NOBRE, H. 2005. Baurusuchus salgadoensis, a new Crocodylomorpha from the Bauru Basin (Cretaceous), Brazil. Gondwana Research, 8: 11-30.

CURRIE, P.J.; RIGBY Jr., J.K.; SLOAN, R.E. 1990. Theropod teeth from the Judith River Formation of Southern Alberta, Canada. In: K. Carpenter \& P.J. Currie (Ed.) Dinosaur systematics: approaches and perspectives. Cambridge, Cambridge University Press, p. 107-125.

ELIAS, F.A., BERTINI, R.J., MEDEIROS, M.A. 2007. Velociraptorinae (Maniraptoriformes) teeth from the Coringa Flagstone outcrop, middle Cretaceous of the São Luís Grajaú Basin, Maranhão State, Northern - Northeastern Brazil. In: I.S. Carvalho et al. (Ed.) Paleontologia: Cenários de Vida. Interciência, Rio de Janeiro, p. 307-317.

FERNANDES, L.A. 1992. A cobertura cretácica suprabasáltica no Estado do Paraná e Pontal do Paranapanema (SP): os grupos Bauru e Caiuá. Instituto de Geociências, Universidade de São Paulo, São Paulo, Dissertação de Mestrado, $171 \mathrm{p}$.

FERNANDES, L.A. 1998. Estratigrafia e evolução geológica da parte Oriental da Bacia Bauru (KS, Brasil). Instituto de Geociências, Universidade de São Paulo, São Paulo, Tese de Doutoramento, $215 \mathrm{p}$.

FERNANDES, L.A.; COIMBRA, A.M. 2000. Revisão estratigráfica da parte Oriental 
da Bacia Bauru (Neo-Cretáceo). Revista Brasileira de Geociências, 30: 717-728.

FRANCO, A.C. 1999. Dentes de teropodomorfos do Cretáceo Superior da Bacia do Paraná. Análise em Microscopia Eletrônica de Varredura. Instituto de Geociências e Ciências Exatas, Universidade Estadual Paulista, Rio Claro, Dissertação de Mestrado, 113 p.

FRANCO, A.C.; BERTINI, R.J. 1997. Structure and ultra-structure of the dental morphology in theropodomorphs dinosaurs (Saurischia: Reptilia). Utility to taxonomy. In: Meeting of the Brazilian Society for Electron Microscopy, 16, Caxambu, Proceedings, 688-689.

GEROTO, C.F.C. 2010. Revisão histórica, prospecção e levantamento dos fósseis de vertebrados, especialmente titanossauros, nas regiões fossilíferas entre Lucélia e Irapuru (Grupo Bauru, Formação Adamantina), Sudoeste do estado de São Paulo. Instituto de Geociências e Ciências Exatas, Rio Claro, Dissertação de Mestrado, 194 p.

GIANECHINI, F.A.; APESTEGUÍA, S. 2011. Unenlagiinae revisited: dromaeosaurid theropods from South America. Anais da Academia Brasileira de Ciências, 83(1): 163-195.

HOLZ, M; SIMÕES, M.G. 2002. Elementos fundamentais de Tafonomia. Editora Universidade/UFRGS, Porto Alegre, 231 p.

KELLNER, A.W.A.; AZEVEDO, S.A.K. 1999. A new sauropod dinosaur (Titanosauria) from the Late Cretaceous of Brazil. In: National Science Museum, Gondwana Dinosaur Symposium, 2, Tokyo, Proceedings: National Science Museum Monographs, 111-142.

KELLNER, A.W.A.; CAMPOS, D.A.; TROTTA, M.N.F. 2005. Description of a titanosaurid caudal series from the Bauru Group, Late Cretaceous of Brazil. Arquivos do Museu Nacional, 63(3): 529-564.

MILANI, E.J. 1997. Evolução tectono-estratigráfica da Bacia do Paraná e seu relacionamento com a geodinâmica fanerozóica do Gondwana Sul-Ocidental. Universidade Federal do Rio Grande do Sul, Porto Alegre, Tese de Doutorado, $255 \mathrm{p}$.
NOVAS, F.E., RIBEIRO, L.C.B., CARVALHO, I.S. 2005. Maniraptoran theropod ungula from the Marilia Formation (Upper Cretaceous), Brazil. Revista do Museo Argentino Ciencias Naturales, 7: 31-35.

NOVAS, F.E.; POL, D.; CANALE, J.I.; PORFIRI, J.D.; CALVO, J.O. 2009. A bizarre Cretaceous theropod dinosaur from Patagonia and the evolution of Gondwanan dromaeosaurids. Proceedings Royal Society, B. 276: 1101-1107.

PAULA E SILVA, F. 2003. Geologia de subsuperfície e Hidroestratigrafia do Grupo Bauru no Estado de São Paulo. Instituto de Geociências e Ciências Exatas, Universidade Estadual Paulista, Rio Claro, Tese de Doutorado, $166 \mathrm{p}$.

PAULA E SILVA, F.; CAVAGUTTI, N. 1994. Nova caracterização estratigráfica e tectônica do Mesozóico na Cidade de Bauru - SP. Geociências, 13(1): 83-99.

PAULA E SILVA, F.; CHANG, H.K.; CAETANOCHANG, M.R. 2003. Perfis de referência do Grupo Bauru (K) no Estado de São Paulo. Geociências, 22 (nº especial): 21-32.

PAULA E SILVA, F.; CHANG, H. K; CAETANOCHANG, M R. 2005. Estratigrafia de subsuperfície do Grupo Bauru (K) no Estado de São Paulo. Revista Brasileira de Geociências, 35(1): 77-88.

PINHEIRO, A.E.P. $2007 . \quad$ Revisões cladística - filogenética e considerações paleobiogeográficas sobre Sebecosuchia (Metasuchia, Crocodylomorpha), do Cretáceo Superior ao Mioceno. Instituto de Geociências e Ciências Exatas, Universidade Estadual Paulista, Rio Claro, Dissertação de Mestrado, $267 \mathrm{p}$.

POWELL, J.E. 1987. The Late Cretaceous fauna of Los Alamitos, Patagonia, Argentina. Part VI. The titanosaurids. Revista Del Museo Argentino de Ciencias Naturales 'Bernardino Rivadavia', 3: 147-153.

POWELL, J.E. 2003. Revision of South American titanosaurid dinosaurs: paleobiological, palaebiogeographical and phylogenetic aspects. Lauceston, Records of the Queen Victoria Museum, 111: $173 \mathrm{p}$. 
PRICE, L.I. 1945. A new reptile from the Cretaceous of Brazil. DNPM, Notas Preliminares e Estudos do Serviço Geológico e Mineralógico, Rio de Janeiro, 25: 8 p.

PRICE, L.I. 1955. Novos crocodilídeos dos arenitos da Série Bauru, Cretáceo do Estado de Minas Gerais. Anais da Academia Brasileira de Ciências, 27: 487-498.

ROMER, A.S. 1997. Osteology of the reptiles. Reprint Edition. Malabar: Krieger Publishing Company, Berlin, 772 p.

SALGADO, L.; CARVALHO, I.S. 2008. Uberabatitan riberoi, a new titanosaur from the Marilia Formation (Bauru Group, Upper Cretaceous), Minas Gerais, SP. Paleontology, 51(4): 881-901.

SALGADO, L.; CORIA, R.A.; CALVO, J.O. 1997. Presencia del Genero Aeolosaurus (Sauropoda, Titanosauridae) en la Formación Los Alamitos, Cretácico Superior de La Província de Rio Negro, Argentina. Revista Universidade de Guarulhos, 2: 44-49.

SANTUCCI, R.M. 1999. Titanossauros neocretácicos do Grupo Bauru: avaliação de ocorrências e de seu potencial paleobiogeográfico e biocronológico. Instituto de Geociências, Universidade de São Paulo, São Paulo, Trabalho de Conclusão de Curso, 57 p.

SANTUCCI, R.M. 2002. Revisão dos Titanosauridae (Saurischia, Sauropoda) do Cretáceo Superior continental da Bacia Bauru. Instituto de Geociências e Ciências Exatas, Universidade Estadual Paulista, Rio Claro, Dissertação de Mestrado, 179 p.

SANTUCCI, R.M.; ARRUDA-CAMPOS, A.C. 2011. A new sauropod (Macronaria, Titanosauria) from the Adamantina Formation, Bauru Group, Upper Cretaceous of Brazil and the phylogenetic relationships of Aeolosaurini. Zootaxa, 3085: 1-33.
SANTUCCI, R.M.; BERTINI, R.J. 2006. A new titanosaur from Western São Paulo State, Upper Cretaceous Bauru Group, Southeast Brazil. Paleontology, 49(1): 59-66.

SOARES, P.C.; LANDIM, P.M.B.; FULFARO, V.J.; SOBREIRO NETO, A.F. 1980. Ensaio de caracterização estratigráfica do Cretáceo no Estado de São Paulo: Grupo Bauru. Revista Brasileira Geociências, 10: 177-185.

STRADIOTO, M.R.; CHANG, H.K.; CAETANOCHANG, M.R. 2008. Caracterização petrográfica e aspectos diagenéticos dos arenitos do Grupo Bauru na região Sudoeste do Estado de São Paulo. Revista da Escola Minas, 61(4): 433-441.

UPCHURCH, P.; BARRET, P.M.; DODSON, P.; 2007. Sauropoda. In: D.B. Weishampel, P. Dodson, H. Osmólka (Ed.) The Dinosauria. Los Angeles, University of California Press, p. 259-232.

WEDEL, M.J. 2005. Postcranial skeletal pneumaticity in sauropods and its implication for mass estimates. In: K.C. Rogers \& J.A. Wilson (Ed.) The sauropods: evolution and paleobiology. Los Angeles, University of California Press, p. 201-227.

WILSON, J.A. 1999. A nomenclature for vertebral laminae in sauropods and other saurischial dinosaurs. Journal of Vertebrate Paleontology, 19(4): 639-653.

WILSON, J.A. 2002. Sauropod dinosaur phylogeny: critique and cladistic analysis. Zoological Journal of the Linnean Society, 136: 217-276.

WILSON, J.A.; SERENO P.C. 1998. Early evolution and higher-level phylogeny of sauropod dinosaurs. Journal of Vertebrate Paleontology, 18, Supplement to Memoir N. 5, (2): 1-68.

\section{Endereço dos autores:}

Caio Fabricio Cezar Geroto e Reinaldo José Bertini - Núcleo de Evolução e Paleobiologia de Vertebrados, Departamento de Geologia Aplicada, Instituto de Geociências e Ciências Exatas, Universidade Estadual Paulista - campus Rio Claro, Av. 24 A - 1515, 13506-900, Rio Claro, SP, Brazil. E-mails: cgeroto@gmail. com, rbertini@rc.unesp.br 